\title{
Human Eosinophil-Granule Major Basic Protein and Synthetic Polycations Induce Airway Hyperresponsiveness In Vivo Dependent on Bradykinin Generation
}

\author{
Anthony J. Coyle, * Steven J. Ackerman, ${ }^{\ddagger}$ Ron Burch, ${ }^{5}$ David Proud," and Charles G. Irvin* \\ *Division of Pulmonary Sciences, Department of Medicine, University of Colorado Health Science Center, and National Jewish Center \\ for Immunology and Respiratory Medicine, Denver, Colorado 80206; ${ }^{\ddagger}$ Infectious Diseases Division, Department of Medicine, Beth Israel \\ Hospital and Harvard Medical School, Boston, Massachusetts 02215; 'Zeneca Pharmaceuticals, Wilmington, Delaware 19897; and \\ "Johns Hopkins Allergy Center, Baltimore, Maryland 21224
}

\begin{abstract}
In the current series of experiments we investigated the role of bradykinin in airway hyperresponsiveness induced by human eosinophil-granule major basic protein (MBP). Bronchoalveolar lavage was performed after intratracheal instillation of MBP or poly-L-lysine in anesthetized, intubated rats, and levels of immunoreactive kinins and kallikrein-like activity were determined. Both MBP and poly-Llysine induced a three- and eightfold increase in levels of kallikrein-like activity and i-kinins, respectively. To determine whether kinin production is required for the development of airway hyperresponsiveness induced by cationic proteins, dose-response curves to methacholine were constructed before and $1 \mathrm{~h}$ after intratracheal instillation of either MBP or poly-L-lysine $(100 \mu \mathrm{g})$. MBP and poly-Llysine induced an increase in airway responsiveness, which was inhibited by pretreatment with a selective BK-2 receptor antagonist, NPC $17713(250 \mu \mathrm{g} / \mathrm{ml})$. Our results demonstrate that MBP and poly-L-lysine activate kallikrein and stimulate the generation of $i$-kinins in vivo, an effect that may be related to the cationic charge of these proteins. Furthermore, the ability of these proteins to increase airway responsiveness appears to be dependent on the generation of i-kinins. (J. Clin. Invest. 1995. 95:1735-1740.) Key words: cationic protein • eosinophil • major basic protein • bradykinin - airway hyperresponsiveness
\end{abstract}

\section{Introduction}

The eosinophil contains at least four distinct cationic granule proteins; the most well characterized is major basic protein (MBP), ${ }^{1}$ an arginine/lysine-rich polypeptide that constitutes

Address correspondence to Anthony J. Coyle, Ph.D., Department of Asthma and Allergy, CIBA, Basel CH4002, Switzerland. Phone: 61697-4489; FAX: 61-697-8403.

Received for publication 22 March 1994 and in revised form 29 September 1994.

1. Abbreviations used in this paper: AHR, airway hyperresponsiveness; BAL, bronchoalveolar lavage; Cdyn, dynamic compliance; MBP, major basic protein; PC 100, provocative concentration required to increase lung resistance $100 \%$; RL, total lung resistance.

J. Clin. Invest.

(c) The American Society for Clinical Investigation, Inc.

0021-9738/95/04/1735/06 \$2.00

Volume 95, April 1995, 1735-1740
$>50 \%$ of the granular protein and $100 \%$ of the core protein of the eosinophil (1). MBP is of considerable interest in the pathogenesis of bronchial asthma as it is highly cytotoxic to airway epithelial cells and induces pathological alterations similar to those found in the airways of asthmatic subjects (2). Elevated levels of MBP have also been reported in the sputum of asthmatic individuals (3). Furthermore, the amount of MBP in the bronchoalveolar lavage (BAL) fluid of asthmatic subjects is correlated with both the degree of epithelial cell denudation and the severity of airway hyperresponsiveness (AHR) (4).

We and others have recently reported that MBP induces AHR in vivo (5-7), an effect mimicked by synthetic cationic proteins such as poly-L-arginine and poly-L-lysine $(6,7)$, suggesting that the high cationic charge of MBP may underlie its ability to increase AHR. This hypothesis was further supported by the demonstration that the effect of MBP could be inhibited by neutralization of its cationic charge with heparin, low molecular weight heparin, or albumin, which are all highly polyanionic molecules (7). However, the precise mechanism(s) by which a charged molecule can alter airway responsiveness remains unknown.

Bradykinin is a 9-amino acid peptide that is generated from its plasma protein precursor, kininogen, by the action of plasma and tissue kallikreins (8) and has a number of properties appropriate to a mediator of asthma (8). Nevertheless, the role of bradykinin in the pathogenesis of allergic airway disease is not well understood. The recent development of peptide analogue antagonists of bradykinin now provide useful tools to elucidate the pathophysiological role of bradykinin.

As it has previously been demonstrated that eosinophil cationic protein can activate plasma kallikrein (9), we have investigated whether human eosinophil MBP and synthetic cationic proteins can stimulate the generation of $\mathrm{i}$-kinins in the airway in vivo. Furthermore, using the selective BK-2 receptor antagonist NPC 17713 ((D)-Arg-Arg-Pro-Hyp-Gly-Phe-Ser-(D)-4hydroxyPro(trans-propyl)-Oic-Arg) (10), we have investigated whether the ability of cationic proteins to induce AHR is dependent on bradykinin formation.

\section{Methods}

Animals. Adult Sprague-Dawley rats of either sex, weighing 200-280 $\mathrm{g}$, were purchased from Sasco (Omaha, NE) and were used throughout this study.

Assessment of lung function. Rats were anesthetized with a mixture of xylazine $(3 \mathrm{mg} / \mathrm{kg})$ and ketamine $(30 \mathrm{mg} / \mathrm{kg})$ administered intraperitoneally, and lung function was measured as described previously ( 6 , 7). Briefly, animals were intubated with a $6-\mathrm{cm}$ long endotracheal tube (PE 205; Intramedic, Becton Dickinson, Parsippany, NJ) and placed in a whole body plethysmograph (model PYLAN; Buxco Electronics, 
Sharon, CT). Tidal volume was monitored as differential pressure $( \pm 2$ $\mathrm{cmH}_{2} \mathrm{O}$; Validyne MP45-871, Validyne Northridge, CA) between the main chamber and a reference chamber filled with copper gauze. A saline-filled catheter was placed in the esophagus to estimate intrapleural pressure and positioned to obtain maximal pressure swings with minimum cardiogenic artifact. Measurements of total lung resistance (RL) and dynamic compliance (Cdyn) were calculated at isovolumetric points using an automated respiratory mechanics analyzer (model 6, Buxco Electronics).

Dose-response curve to inhaled bradykinin. After measurements of baseline lung function, rats were exposed for $15 \mathrm{~s}$ to an aerosol of saline generated by an air-driven ultrasonic nebulizer (pulmosonic, model 25; Devilbiss, Somerset, PA), which had previously been demonstrated to generate particles with a mean diameter of $3.5 \mu \mathrm{m}$. Animals were exposed to increasing concentrations of bradykinin (Sigma Chemical Co., St. Louis, MO) $(1.0,3.0$, and $10.0 \mathrm{mg} / \mathrm{ml})$, for $15 \mathrm{~s}$ at each dose. Bradykinin was prepared in PBS, pH 6.4. The effect of inhaled bradykinin on pulmonary function was studied on three separate study days, separated by at least $48 \mathrm{~h}$. Animals were treated in a randomized fashion with an aerosol for $3 \mathrm{~min}$ of either saline, $5 \mathrm{~min}$ before bradykinin challenge; NPC $17713(250 \mu \mathrm{g} / \mathrm{ml}), 5 \mathrm{~min}$ before bradykinin; or NPC $17713(250 \mu \mathrm{g} / \mathrm{ml}), 60 \mathrm{~min}$ before bradykinin.

Determination of airway responsiveness to methacholine. After measurements of baseline lung function, rats were exposed to an aerosol of saline for $15 \mathrm{~s}$ as previously described. Animals were then exposed to increasing concentrations of methacholine (Sigma Chemical Co.) $(0.18-5.0 \mathrm{mg} / \mathrm{ml})$, for $15 \mathrm{~s}$ at each dose until there was at least a doubling in RL. The provocative concentration of methacholine required to increase RL by $100 \%$ (PC 100) was calculated by linear interpolation and used as an index of airway responsiveness. Previous experiments had shown that this procedure allows highly reproducible PC 100 values (less than half a doubling dose) to be performed.

In a group of animals, dose-response curve to methacholine were constructed before and 15 and $60 \mathrm{~min}$ after exposure to a submaximal concentration of bradykinin $(3 \mathrm{mg} / \mathrm{ml})$ by aerosol for $3 \mathrm{~min}$.

Preparation of MBP. Human MBP was prepared as described previously (1). Briefly, human eosinophils were purified, and the granules were obtained by hypertonic disruption of the cells in $0.25 \mathrm{M}$ sucrose, followed by centrifugation at $600 \mathrm{~g}$ to pellet unbroken cells and at $40,000 \mathrm{~g}$ to pellet the granules. The granules were then lysed in 0.01 $\mathrm{N} \mathrm{HCl}$ with sonication, and MBP was separated using a Sephadex G50 column, equilibrated with $0.025 \mathrm{M}$ acetate buffer, $\mathrm{pH} 4.2$, containing $0.15 \mathrm{M} \mathrm{NaCl}$. MBP was stored at a final concentration of $600 \mu \mathrm{g} / \mathrm{ml}$ at $-80^{\circ} \mathrm{C}$. As a control, a pool of prevoid volume fractions from the Sephadex G-50 column was used and is referred to in the text as the buffer control.

Instillation of cationic proteins. After the resolution of the bronchoconstriction induced by methacholine (usually $15-20 \mathrm{~min}$ ), $320 \mu \mathrm{l}$ of MBP $(300 \mu \mathrm{g} / \mathrm{ml})$ was instilled in the airways via the endotracheal tube using a 23-gauge needle positioned at the carina. $15 \mathrm{~min}$ before instillation of MBP, animals were exposed to either an aerosol of saline for $3 \mathrm{~min}$ or NPC $17713(250 \mu \mathrm{g} / \mathrm{ml})$ for an equivalent period of time. Similarly, animals were pretreated with either saline or NPC 177135 $\min$ before instillation of $100 \mu \mathrm{l}$ of poly-L-lysine $(1 \mathrm{mg} / \mathrm{ml})$. In another series of experiments, animals were treated with NPC $1771345 \mathrm{~min}$ after poly-L-lysine instillation. Control animals received an aerosol of saline as an appropriate control. Airway responsiveness after instillation of either MBP or poly-L-lysine was measured $1 \mathrm{~h}$ later.

Measurement of immunoreactive kinins and kallikrein-like activity. In another series of animals, BAL was performed 5, 15, or 60 min after instillation of poly-L-lysine by injecting $6 \mathrm{ml}$ of sterile saline into the lungs via the tracheal cannula. The fluid was immediately aspirated and divided into three aliquots. Bradykinin was measured using a specific RIA as described previously (11). Briefly, the BAL fluid was mixed with TCA ( $10 \%$ [wt/vol] final concentration) and centrifuged at 5,000 $g$ for $30 \mathrm{~min}$. Samples were then dried using vacuum centrifugation and redissolved in RIA buffer. $\left[{ }^{3} \mathrm{H}\right]$ bradykinin was used as the tracer, and antisera were used at a final concentration of 1:30,000. After an incuba- (a) $5 \mathrm{~min}$ before
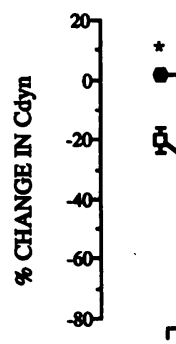

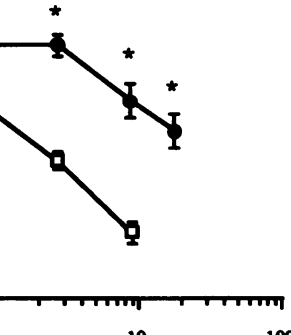

(b) $1 \mathrm{~h}$ before $\star$

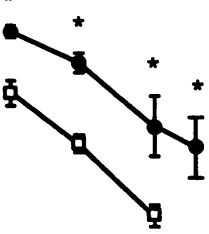

100
Figure 1. Modification of bradykinin-induced bronchoconstriction by NPC $17713(250 \mu \mathrm{g} / \mathrm{ml})$ (closed circles). Control animals were exposed to an aerosol of saline alone (open squares). Animals were treated with NPC 17713, $5(a)$ or $60(b)$ min before bradykinin provocation. Results are expressed as the mean \pm SEM of the percent change in Cdyn for $n=6$ animals. Significance $(* P<0.01)$ was determined by a Student's $t$ test.

tion period of $18 \mathrm{~h}$ at $4^{\circ} \mathrm{C}$, the assay was terminated with charcoal dextran. This protocol recovers $95 \%$ of standard bradykinin, with a detection limit of $5 \mathrm{pg}$ per $\mathrm{ml}$ of BAL fluid. Cross-reactivity is $5,000 \%$

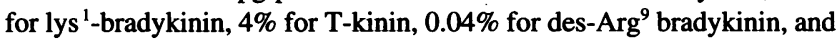
negligible for substance $P$, vasoactive intestinal peptide, and bombesin.

Kallikrein-like activity was measured as arginine esterase activity using the TAME-esterase assay (12). An aliquot $(20 \mu \mathrm{l})$ of BAL fluid (without TCA) was added to $0.05 \mu \mathrm{Ci}$ of $N$ - $\alpha$-tosyl-L-arginine ([ $\left.{ }^{3} \mathrm{H}\right]-$ methylester) in $2 \mathrm{M}$ Tris, $\mathrm{pH} 8$, and incubated at $30^{\circ} \mathrm{C}$ with $10 \mathrm{ml}$ of nonaqueous counting fluid plus $50 \mu \mathrm{l}$ of a stopping solution of $0.02 \mathrm{M}$ TAME (Schwartz Mann, ICN, Costa Mesa, CA) and acetic acid (9:1). After $30 \mathrm{~min}$, the reaction was stopped, and the $\left[{ }^{3} \mathrm{H}\right]$ methanol product was counted. Following the determination of the time course of kinin generation after poly-L-lysine instillation, a single period of $15 \mathrm{~min}$ was used to determine whether MBP could stimulate kinin formation. Furthermore, to investigate whether the cationic charge of poly-L-lysine was responsible for kinin generation, $2 \mathrm{mg} / \mathrm{ml}$ poly-L-lysine was mixed with $1 \mathrm{mg} / \mathrm{ml}$ low molecular weight heparin, a concentration we have previously demonstrated to inhibit poly-L-lysine-induced AHR (7), and $100 \mu \mathrm{l}$ was instilled intratracheally. BAL was performed $15 \mathrm{~min}$ later, and levels of i-kinins and kallikrein-like activity were determined as previously described. As a control, the effect of $100 \mu \mathrm{l}$ of low molecular weight heparin $(500 \mu \mathrm{l} / \mathrm{ml})$ or $100 \mu \mathrm{l}$ of poly-L-aspartate $(1 \mathrm{mg} /$ $\mathrm{ml}$ ) on mediator production in the BAL fluid was assessed.

\section{Results}

Inhibition of bradykinin-induced bronchoconstriction by NPC 17713. Exposure to an aerosol of bradykinin induced a dosedependent fall in Cdyn (Fig. 1). In contrast to changes in Cdyn, inhaled bradykinin induced minor changes in RL, suggesting that bradykinin acts preferentially on the smaller airways (data not shown). NPC 17713 antagonized bradykinin-induced bronchoconstriction. The effect was maximal when given 5 min before bradykinin challenge (Fig. $1 a$ ), although a significant protection was afforded when given $60 \mathrm{~min}$ before bradykinin (Fig. $1 b)$.

Inhibition of MBP- and poly-L-lysine-induced AHR. Instillation of MBP induced a two- to threefold increase in AHR as previously reported $(6,7)$ (PC 100: $1.20[1.24-1.16] \mathrm{mg} / \mathrm{ml}$ $0.66[0.85-0.64] \mathrm{mg} / \mathrm{ml}, n=4, P<0.05)$. Pretreatment with NPC $17713(250 \mu \mathrm{g} / \mathrm{ml})$ inhibited MBP-induced increased air- 


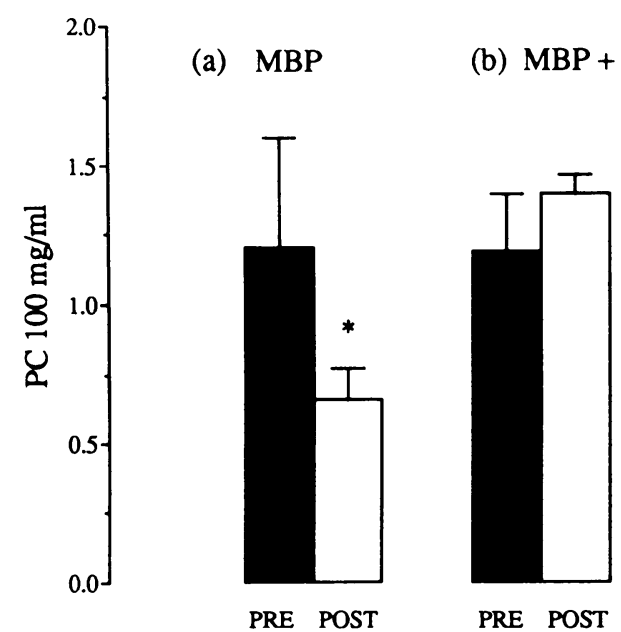

Figure 2. The effect of human eosinophil-granule MBP on airway responsiveness. Results are expressed as the mean \pm SEM of the PC 100 before (closed columns) and $1 \mathrm{~h}$ after instillation of MBP $(100 \mu \mathrm{g})$ (open columns) in $(a)$ control animals or $(b)$ animals that were pretreated with NPC $17713(250 \mu \mathrm{g} / \mathrm{ml}) 5 \mathrm{~min}$ before MBP instillation. Significance $(* P<0.05$ ) was determined by a Student's $t$ test.

way responsiveness (PC 100: $1.19[1.40-1.02] \mathrm{mg} / \mathrm{ml} ; 1.40$ [1.47-1.34] mg/ml, $n=3, P<0.05$ ) (Fig. 2). In agreement with our previous results $(6)$, there was no difference in the resting airway caliber before instillation of MBP or $1 \mathrm{~h}$ later, immediately before the second dose response to methacholine (data not shown).

Similarly, instillation of poly-L-lysine increased airway responsiveness (PC 100: $1.14[0.93-1.39] \mathrm{mg} / \mathrm{ml} ; 0.13[0.14-$ $0.12] \mathrm{mg} / \mathrm{ml}, n=6, P<0.01$ ) (Fig. $3 a$ ). Pretreatment with NPC 17713 markedly attenuated poly-L-lysine-induced AHR (PC 100: 0.90 [0.79-1.00] mg/ml; 0.57 [0.77-0.43] mg/ml.

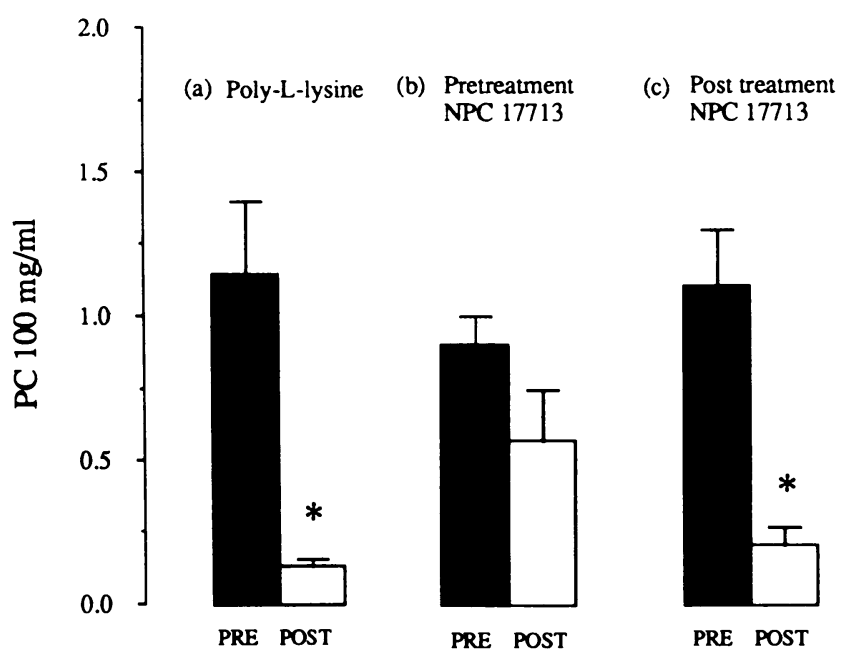

Figure 3. The effect of NPC 17713 on poly-L-lysine-induced AHR. Airway responsiveness is shown as the mean \pm SEM of the PC 100 before (closed columns) and $1 \mathrm{~h}$ after instillation of poly-L-lysine (open columns) in $(a)$ control animals, $(b)$ animals pretreated with NPC 17713 , and $(c)$ animals treated with NPC 1771345 min after poly-Llysine instillation for $n=5-8$ animals. Significance $(* P<0.01$ ) was determined by a Student's $t$ test. (a)

(b)
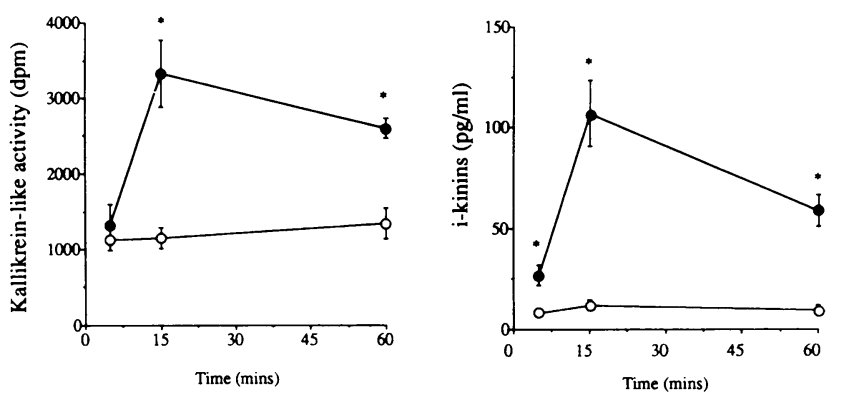

Figure 4. Time course of generation of $(a)$ kallikrein-like activity and (b) immunoreactive kinins after intratracheal instillation of poly-L-lysine (closed circles) or saline (open circles). Significance $(* P<0.01$ ) was determined by a Student's $t$ test.

$n=6, P<0.01$ ). (Fig. $3 b$ ). In contrast to the efficacy of NPC 17713 when given before poly-L-lysine instillation, exposure to NPC $1771345 \mathrm{~min}$ after poly-L-lysine failed to inhibit the increased airway responsiveness (PC 100: $1.1[0.9-1.23] \mathrm{mg} /$ $\mathrm{ml} ; 0.21[0.15-0.29] \mathrm{mg} / \mathrm{ml}$ ) (Fig. $3 c$ ). There was no change in responsiveness to methacholine in animals that were pretreated with NPC 17713 and received an intratracheal instillation of saline (data not shown).

Time course of activation of kallikrein-like activity and bradykinin generation. Poly-L-lysine increased kallikrein-like activity in the lung, which was maximal 15 min after instillation $(3,324.8 \pm 444 \mathrm{dpm}, n=4)$ compared with saline-treated animals $(1,151.7 \pm 138 \mathrm{dpm}, n=6, p<0.001) .60 \mathrm{~min}$ after instillation, levels of kallikrein were reduced compared with 15 min after instillation $(2,597 \pm 133 \mathrm{dpm}, n=3)$, but were still elevated compared with those in saline-treated animals $(1,339 \pm 133 \mathrm{dpm}, n=3, P<0.05)$ (Fig $4 a$ ). Concomitant with the increase in kallikrein-like activity, there was an increase in the amount of i-kinins in the airways, which was maximal $15 \mathrm{~min}$ after instillation (poly-L-lysine treated: $107.0 \pm 16.3 \mathrm{pg} / \mathrm{ml}, n=9$; saline treated: $12.0 \pm 2.7 \mathrm{pg} / \mathrm{ml}, n$ $=9, P<0.001)($ Fig. $4 b)$. Similarly, kinin levels were reduced 60 min later, but were still elevated as compared with control animals (poly-L-lysine treated: $58.5 \pm 7.8 \mathrm{pg} / \mathrm{ml}, n=8$; saline treated: $9.3 \pm 2.5 \mathrm{pg} / \mathrm{ml}, n=4, P<0.005)$. Poly-L-lysineinduced kallikrein activation and kinin generation was inhibited by admixing the cationic protein with low molecular weight heparin $(1,758.3 \pm 186.5 \mathrm{dpm}$ and $24.0 \pm 2.0 \mathrm{pg} / \mathrm{ml}, n=6, P$ $<0.01$, respectively) (Fig. 5, $a$ and $b$ ). Instillation of low molecular weight heparin or poly-L-aspartate had little effect on kallikrein-like activity and i-kinin production (Fig. 5, $a$ and $b$ ).

Effect of MBP on kallikrein activation and kinin generation. Instillation of MBP produced a twofold increase in the levels of kallikrein-like activity in BAL fluid compared with animals treated with the control buffer (MBP: 2,812 $2394 \mathrm{dpm}, n=4$; column buffer void: $1,470 \pm 136 \mathrm{dpm}, n=4, P<0.01$ ). Similarly, MBP induced a fivefold increase in the levels of i-kinins in the airways (MBP: $63.5 \pm 12.1 \mathrm{pg} / \mathrm{ml}, n=4$; control: $12.3 \pm 2.7 \mathrm{pg} / \mathrm{ml}, n=4, P<0.01$ ) (Fig. 6 ).

Effect of bradykinin on airway responsiveness to methacholine. Exposure to an aerosol of bradykinin failed to increase AHR to methacholine at either $15 \mathrm{~min}$ before (PC 1001.15 [0.90-1.28 mg/ml]), or $15 \mathrm{~min}$ ( PC 100: 1.43 [1.17-1.65 mg/ 
(a)
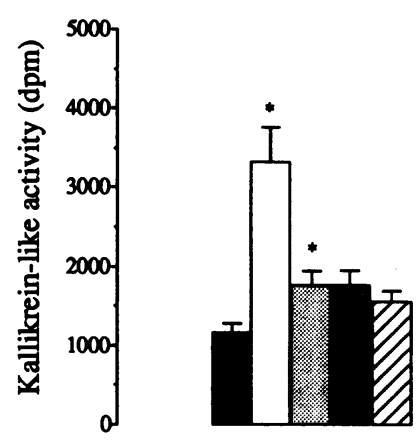

(b)

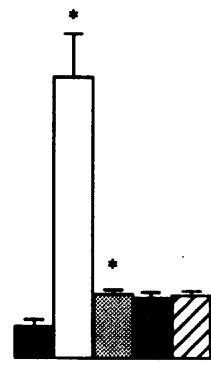

Figure 5. Modification of poly-L-lysine-induced (a) kallikrein activation and $(b)$ i-kinin generation by low molecular weight heparin. BAL were performed $15 \mathrm{~min}$ after instillation following saline (open columns), poly-L-lysine (closed), or poly-L-lysine + heparin (dotted). The effects of heparin (vertically striped) or poly-L-aspartate alone (diagonal striped) are shown for comparison. Significance $(* P<0.01)$ was determined by a Student's $t$ test.

$\mathrm{ml}$ ], $n=5, P>0.1$ ) or $60 \mathrm{~min}$ (PC 100: $1.22[1.12-1.34 \mathrm{mg} /$ $\mathrm{ml}$ ], $n=5, P>0.1$ ) after bradykinin challenge.

\section{Discussion}

The possible involvement of kinins in inflammatory airway diseases such as bronchial asthma has been a subject of much speculation. However, with the recent introduction of selective receptor antagonists, the pathophysiological role of these peptides can be investigated. In the present series of experiments, we have demonstrated that human eosinophil-granule MBP and a synthetic cationic protein, poly-L-lysine, can stimulate the generation of i-kinins in the airways. Furthermore, using the selective receptor antagonist NPC 17713 (10), we have shown that the ability of these proteins to induce AHR is in part dependent on bradykinin formation.

The mechanisms by which bradykinin contributes to cationic protein-induced AHR are unclear. However, whatever the precise role of this peptide, bradykinin involvement appears to be an early event, as the antagonist was ineffective when given after poly-L-lysine instillation. These functional observations are supported by the demonstration that BAL fluid levels of kallikrein-like activity and i-kinins were elevated above those in control animals as early as 5 min after instillation, peaking at $15 \mathrm{~min}$ and returning toward baseline $1 \mathrm{~h}$ later. As $15 \mathrm{~min}$ proved to be the optimum period for i-kinin generation after poly-L-lysine instillation, this time period was used to determine whether MBP also activated the kinin system. After instillation of MBP, we were also able to demonstrate a two- and fivefold increase in the amount of kallikrein-like activity and i-kinins, respectively, as compared with that induced by the column prevoid volume control. However, it is important to note that measurement of the level of $i$-kinins is an assessment of both bradykinin and lysylbradykinin (kallidin), and thus in the present study it was not possible to distinguish between the formation of these two peptides and their relative importance in the development of AHR.

In clinical studies, elevated levels of i-kinins and tissue (a)

(b)
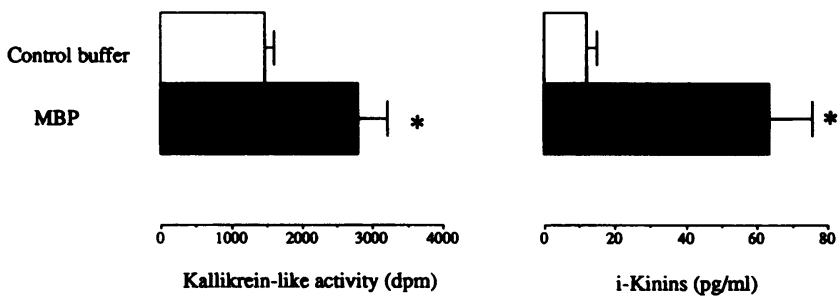

Figure 6. The effect of MBP (closed columns) on (a) kallikrein generation and $(b)$ immunoreactive kinins. The effect of the prevoid column fraction was used as a control for MBP (open columns) and is shown for comparison. Significance $(* P<0.01)$ was determined by a Student's $t$ test.

kallikrein have been detected in the BAL fluid of asthmatics (13) and, more recently, in the BAL fluid of asthmatic subjects after allergen challenge (14). In addition, increased amounts of kinins have been demonstrated after nasal challenge with allergen $(15,16)$, cold, dry air (17), and viral infection (18). It is of considerable relevance to our present observations that levels of i-kinins after nasal provocation were well correlated with levels of eosinophil cationic protein, suggesting a link between eosinophilic inflammation and kinin generation (16). However, from this study it is not possible to determine whether eosinophil activation and cationic protein release were responsible for the increased i-kinin level in the nasal washes. A biphasic elevation in both i-kinins and kallikrein-like activity has also been reported in the BAL fluid of ascaris-sensitive sheep after allergen provocation (11), with the two peaks of i-kinin activity corresponding to the early and late phase airway obstructive response. Moreover, pretreatment with the BK-2 receptor antagonist NPC 567 inhibited both the development of the late phase response and the heightened airway responsiveness (11). Thus, based on our observations, it is reasonable to speculate that granulocyte infiltration with the subsequent release of cationic proteins, an event associated with the late phase asthmatic response and AHR, may be responsible for the second peak of ikinins in this model.

During allergic inflammation of the human upper airways, it has been shown that three enzymes contribute to TAMEesterase-like activity, tissue kallikrein, plasma kallikrein, and mast cell tryptase $(19,20)$. Both kallikreins are potent inducers of kinin formation and so could contribute to the generation of kinins in the present study. Tissue kallikrein has been shown to be present in the serous cells of the submucosal glands in the lower airways (21), and plasma kallikrein may be expected to enter into the airway secretions as a result of plasma transudation. Although it has been shown that mast cell-derived tryptase can generate kinins under certain circumstances and is responsible for the kininogenase activity released from sensitized human lung mast cells after antigen challenge (22), it is unlikely to be a significant contributor to kinin generation in vivo, since this enzyme requires an optimal $\mathrm{pH}$ of 5.5 and, even at this $\mathrm{pH}$, is $<1 \%$ as efficient as kallikreins in generating kinins (23). In the present study, however, we have not attempted to characterize further the nature of the TAME-esterase activity, as based on the levels observed, we anticipate that the amount of tissue kallikrein in the lavage fluid would be below detection. More- 
over, plasma kallikrein is difficult to measure because this enzyme is rapidly metabolized by protease inhibitors. Therefore, at present, the precise source(s) of the kallikrein-like activity after MBP instillation is unknown.

The ability of poly-L-lysine to generate kinins in the lung appears to be dependent on the highly charged nature of this protein, as neutralization of the cationic charge with low molecular weight heparin, a polylinear anion, inhibited bradykinin generation. Such results are consistent with our previous observations that cationic charge is an important determinant of the ability of these proteins to increase airway responsiveness (7). To our knowledge, this is the first report that such cationic proteins can activate kallikrein and stimulate kinin formation on the basis of a positive charge interaction. However, it has previously been reported that eosinophil cationic protein can activate plasma kallikrein by a Factor XII-dependent mechanism (12); although the role of charge-dependent interactions was not investigated in this study. In contrast to the lack of information on the effect of basic proteins on kallikrein activation, it is well documented in vitro that negatively charged surfaces such as heparin and dextran sulfate can interact with Factor XII, prekallikrein, and high molecular weight kininogen to stimulate kinin formation (8). However, under our experimental conditions, instillation of heparin and poly-L-aspartate produced only a barely detectable increase in the levels of ikinins and kallikrein-like activity compared with those in salinetreated animals and was comparable to changes in kinin production induced by instillation of the biologically inactive prevoid volume column buffer control for MBP.

Our results also suggest a basis for the further investigation of the use of polyanionic agents in the treatment of allergic disease. In experimental animal models, heparin has been demonstrated to inhibit smooth muscle proliferation (24) and antigen-induced eosinophil infiltration (25). Furthermore, clinical studies have demonstrated that heparin will inhibit exerciseinduced bronchoconstriction (26). The importance of charge neutralization in mediating these effects remains to be determined.

Although we were able to demonstrate an important role for bradykinin in cationic protein-induced AHR, we were unable to show that bradykinin alone would increase airway responsiveness to methacholine. Our observations support those of Abraham et al., who demonstrated that although bradykinin failed to increase airway responsiveness to methacholine (27), inhibition of bradykinin with the selective antagonist NPC 567 inhibited the development of antigen-induced AHR in allergic sheep (28). Thus while the generation of bradykinin is central to the expression of airway responsiveness induced by either allergen (28) or MBP (this study), bradykinin formation per se is insufficient to increase responsiveness. These observations suggest that although bradykinin has a central role in the development of AHR, an additional factor(s) is also required. Such a factor could be modification of epithelial permeability (29, 30 ), loss of an epithelium-derived relaxant factor (30), or activation of sensory C-fibers (31).

Bradykinin may contribute to the development of AHR by a number of different mechanisms. These include the generation of a variety of secondary mediators, such as metabolites of arachidonic acid $(32,33)$ and platelet-activating factor $(33)$, which may serve to amplify the airway effects of bradykinin. Bradykinin is a potent inducer of plasma protein extravasation, which occurs via a BK-2 receptor-mediated mechanism (34-
36). In addition, bradykinin can activate neural pathways in the airways by stimulating both vagal afferent C-fibers (37) and unmyelinated sensory C-fibers (38). In this regard, bradykinin has been demonstrated to be a potent stimulator of sensory neuropeptide release from perfused guinea pig lungs, being some 100 times more potent than histamine (38). The ability of bradykinin to induce plasma protein extravasation appears to be dependent on activation of sensory C-fibers, as pretreatment with the selective $\mathrm{C}$-fiber neurotoxin capsaicin inhibits bradykinin-induced vascular leakage (39). Likewise, in guinea pigs, bradykinin-induced bronchoconstriction can be abrogated by pretreatment with atropine and capsaicin, suggesting the involvement of both cholinergic and excitatory noncholinergic neural mechanisms (40). More recently it has been demonstrated in rodents that bradykinin-induced vascular leakage is dependent on substance $\mathrm{P}$ release from afferent $\mathrm{C}$-fibers, as the effect of bradykinin is inhibited by the selective NK-1 receptor antagonist CP-96, 345 (41). Bradykinin can also facilitate noncholinergic excitatory responses in guinea pig airways by a prejunctional mechanism, the effect of which could be inhibited by a selective BK-2 receptor antagonist (42). These observations suggest that BK-2 receptors are present on sensory nerve endings in the airways and support previous electrophysiological evidence that the effects of bradykinin on sensory neurons in the spinal cord and cultured sensory neurons are mediated by BK-2 receptors (43). Thus, cationic protein-induced bradykinin generation may lead to a cascade of events resulting in the development of AHR.

In conclusion, we have demonstrated that, in an experimental system, an acute instillation of eosinophil-granule MBP as well as a synthetic cationic protein can generate bradykinin, which is important in the subsequent development of AHR. Our observations are important, as they demonstrate that MBP induces AHR by mechanisms other than a direct cytotoxic action on the airway epithelium. The precise relationship between MBP release, kinin generation, and the subsequent development of AHR in the asthmatic individual remains to be determined. However, as cationic proteins can be released from eosinophils by an IgE-dependent mechanism (44), the possibility exists that bradykinin may be generated in the lungs as a result of allergen-induced eosinophil degranulation. Finally, our data suggest that if indeed this is the case, bradykinin antagonists may prove to be novel antiasthmatic agents.

\section{Acknowledgments}

We would like to thank Dr. John Stewart for valuable discussions.

This study was supported by grants AI-25230 and AI-22660 from the National Institute of Allergy and Infectious Diseases to S. J. Ackerman, and grant POI-37665 from the National Institutes of Health to D. Proud.

\section{References}

1. Ackerman, S. J., D. A. Loegering, P. Venge, I. Olsson, J. B. Harley, A. S. Fauci, and G. J. Gleich. 1983. Distinctive cationic proteins of the human eosinophil granule: major basic protein, eosinophil cationic protein and eosinophilderived neurotoxin. J. Immunol. 131:2977-2982.

2. Motojima, S., E. Frigas, D. A. Loegering, and G. J. Gleich. 1989. Toxicity of eosinophil cationic proteins for guinea pig tracheal epithelium in vitro. Am. Rev. Respir. Dis. 139:801-805.

3. Frigas, E., D. A. Loegering, G. O. Solley, G. M. Farrow, and G. J. Gleich. 1981. Increased levels of eosinophil granular major basic protein in the sputum of patients with bronchial asthma. Mayo Clin. Proc. 56:345-353. 
4, Wardlaw, A. J., S. Dunette, G. J. Gleich, J. V. Collins, and A. B. Kay. 1988. Eosinophils in the bronchoalveolar lavage fluid in subjects with mild asthma. Am. Rev. Respir. Dis. 137:62-70.

5. Gundel, R. H., G. Letts, and G. J. Gleich. 1991. Human eosinophil major basic protein induces airway constriction and airway hyperresponsiveness in non human primates. J. Clin. Invest. 87:1470-1473.

6. Uchida, D. A., A. J. Coyle, S. J. Ackerman, P. F. Weller, G. L. Larsen, and C. G. Irvin. 1993. The effects of human eosinophil granule major basic protein on rat airways responsiveness in vivo: a comparison with polycations. Am. Rev. Respir. Dis. 147:982-988.

7. Coyle, A. J., S. Ackerman, and C. G. Irvin. 1993. Cationic proteins induce airway hyperresponsiveness dependent on charge interactions. Am. Rev. Respir. Dis. 147:896-900.

8. Proud, D., and A. P. Kaplan. 1988. Kinin formation. Mechanisms and role in inflammatory disorders. Annu. Rev. Immunol. 6:49-83.

9. Venge, P., R. Dahl, and R. Hallgren. 1979. Enhancement of factor XII reactions by eosinophil cationic protein. Thromb. Res. 14:641-649.

10. Burch, R. M., and D. J. Kyle. 1992. Recent developments in the understanding of bradykinin receptors. Life Sci. 50:829-838.

11. Abraham, W. M., R. M. Burch, S. G. Farmer, M. W. Sielczak, A. Ahmed, and A. Cortes. 1991. A bradykinin antagonist modifies allergen induced mediator release and late bronchial responses in sheep. Am. Rev. Respir. Dis. 143:787796.

12. Imanari, T., T. Kaizu, H. Yoshida, K. Yates, J. V. Pierce, and J. J. Pisano. 1976. Radiochemical assays for urinary, salivary and plasma kallikreins. In Chemistry and Biology of the kallikrein-Kinin System in Health and Disease. J. J. Pisano and K. F. Austin, editors. U. S. Department of Health, Education and Disease. U. S. Government Printing Office, Washington, DC. 205-213.

13. Christiansen, S. C., D. Proud, and C. G. Cochrane. 1987. Detection of tissue kallikrein in the bronchoalveolar lavage fluid of asthmatic subjects. J. Clin. Invest. 79:188-197.

14. Christiansen, S. C., D. Proud, R. B. Sarnoff, U. Juergens, C. G. Cochrane and B. L. Zuraw. 1992. Elevation of tissue kallikrein and kinin in the airways of asthmatic subjects after endobronchial allergen challenge. Am. Rev. Respir. Dis. 145:900-905

15. Proud, D., A. Togias, N. M. Naclerio, S. A. Crush, P. S. Norman, and L. M. Lichtenstein. 1983. Kinins are generated in vivo following nasal airway challenge of allergic individuals with allergen. J. Clin. Invest. 72:1678-1685.

16. Svensson, C., M. Andersson, C. G. A. Persson, P. Venge, U. Alkner, and U. Pipkorn. 1990. Albumin, bradykinins and eosinophil cationic protein on the nasal mucosal surface in patients with hay fever during natural allergen exposure. J. Allergy Clin. Immunol. 85:828-833.

17. Togias, A. G., R. M. Naclerio, D. P1oud, J. E. Fish, N. F. Adkinson, A. K. Sobotka, P. S. Norman, and L. M. Lichtenstein. 1985. Nasal challenge with cold, dry air results in the release of inflammatory mediators: possible mast cell involvement. J. Clin. Invest. 76:1375-1381.

18. Naclerio, R. M., J. M. Gwaltney, J. O. Hendley, P. Egglestom, C. R. Baumgarten, L. M. Lichtenstein, and D. Proud. 1985. Kinins are generated during rhinovirus colds. Clin. Res. 33:613. (Abstr.)

19. Baumgarten, C. R., R. C. Nichols, R. M. Naclerio, L. M. Lichtenstein, P. S. Norman, and D. Proud. 1986. Plasma kallikrein during experimentally induced allergic rhinitis: role in kinin formation and contribution to TAME-esterase activity in nasal secretions. J. Immunol. 137:977-982.

20. Baumgarten, C. R., R. C. Nichols, R. M. Naclerio, and D. Proud. 1986. Concentrations of glandular kallikrein in human nasal secretions increase during experimentally induced allergic rhinitis. J. Immunol. 137:1323-1328.

21. Proud, D., and C. P. Vio. 1993. Localisation of immunoreactive tissue kallikrein in human trachea. Am. J. Respir. Cell. Mol. Biol. 8:16-19.

22. Proud, D., D. W. MacGlashan, Jr., N. M. Newball, E. S. Shulman, and L. M. Litchenstein. 1985. Immunoglobulin-E mediated release of a kininogenase from purified human lung mast cells. Am. Rev. Respir. Dis. 132:405-408.

23. Proud, D., E. S. Siekierski, and G. S. Bailey. 1988. Identification of human lung mast cell kininogenase as tryptase and release of trypase kininogenase activity. Biochem. Pharmacol. 37:1473-1480.
24. Hassoun, P. M., B. T. Thompson, D. Steigman, and C. A. Hales. 1989. Effect of heparin and warfarin on chronic hypoxic pulmonary hypertension and vascular remodelling in the guinea pig. Am. Rev. Respir. Dis. 139:763-768.

25. Hanss, J., M. Woods, A. J. Coyle, and C. P. Page. 1989. The effect of heparin and related compounds on PAF and antigen induced eosinophil infiltration Am. Rev. Respir. Dis. 139:134. (Abstr.)

26. Ahmed, T., J. Garrigo, and I. Danta. 1993. Preventing bronchoconstriction in exercise induced asthma with inhaled heparin. N. Engl. J. Med. 329:90-95.

27. Abraham, W. M., L. E. Baugh, S. L. Harbeson, A. Cortes, and A. Ahmed 1989. Airway effects of bradykinin, substance $P$ and neurokinin $A$ in allergic sheep. Am. Rev. Respir. Dis. 139:239. (Abstr.)

28. Soler, M., M. W. Sielczak, and W. M. Abraham. 1990. A bradykinin antagonist inhibits antigen induced airway hyperresponsiveness and inflammation in sheep. Pulm. Pharmacol. 3:9-15.

29. Peterson, M. W., and D. Gruenhaupt. 1990. Protamine increases the permeability of cultured epithelial cells monolayers. J. Appl. Physiol. 68:220-227.

30. Coyle, A. J., W. Mitzner, and C. G. Irvin. 1993. A synthetic cationic protein alters smooth muscle function by an epithelial dependent mechanism. $J$. Appl. Physiol. 74:1761-1768.

31. Coyle, A. J., F. Perretti, S. Manzini, and C. G. Irvin. 1994. Sensory nerve activation induced by synthetic cationic proteins. Role of tachykinins in airway hyperresponsiveness and plasma protein extravasation. Am. Rev. Respir. Dis. 147:854. (Abstr.)

32. McIntyre, T. M., G. A. Zimmerman, K. Satoh, and S. M. Prescott. 1985 Cultured endothelial cells synthesize both platelet activating factor and prostacyclin in response to histamine, bradykinin, and adenosine triphosphate. J. Clin. Invest. 76:271-280.

33. Jelsema, C. L., J. Moss, and V. C. Manganiello. 1985. Effect of bradykinin on prostaglandin production by human skin fibroblasts in culture. Methods Enzymol. 109:480-503.

34. Rodgers, D. F., S. Dijk, and P. J. Barnes. 1989. Bradykinin microvascular leakage in guinea pig airways in vivo: involvement of platelet activating factor. Am. Rev. Respir. Dis. 137:236. (Abstr.)

35. Ichinose, M., and P. J. Barnes. 1990. Bradykinin induced airway microvascular leakage and bronchoconstriction are mediated via a bradykinin B2 receptor Am. Rev. Respir. Dis. 142:1104-1107.

36. Sakamoto, T., W. Elwood, P. J. Barnes, and K. F. Chung. 1992. Effect of HoE 140, a new bradykinin receptor antagonist, on bradykinin and platele activating factor-induced broncoconstriction and airway microvascular leakage in the guinea pig. Eur. J. Pharmacol. 213:367-373.

37. Kaufman, M. P., K. M. Coleridge, J. C. C. Coleridge, and D. C. Baker. 1980. Bradykinin stimulates afferent C-fibres in intrapulmonary airways of dogs. J. Appl. Physiol. 48:511-517.

38. Saria, A., C. R. Martling, Z. Yan, E. Theodorsson-Norheim, R. Gamse, and J. M. Lundberg. 1985. Release of multiple tachykinins from capsaicin sensitive nerves in the lungs by bradykinin, histamine, dimethylphenylpiperazinium and vagal nerve stimulation. Am. Rev. Respir. Dis. 137:1330-1335.

39. Lundberg, J. M., and A. Saria. 1983. Capsaicin induced desensitisation of airway mucosa to cigarette smoke, mechanical and chemical irritants. Nature (Lond.) 235:251-261

40. Ichinose, M., M. G. Belvisi, and P. J. Barnes. 1990. Bradykinin induced bronchoconstriction in guinea pigs in vivo: role of neural mechanisms. J. Pharmacol. Exp. Ther. 253:594-599.

41. Bertrand, C., P. Geppetti, J. Baker, G. Petersson, G. Piedimonte, and J. A. Nadel. 1993. Role of peptidases and NK-1 receptors in vascular extravasation induced by bradykinin in rat nasal mucosa. J. Appl. Physiol. 74:2456-2461.

42. Miura, M., Belvisi, M. G., and P. J. Barnes. 1993. Effect of bradykinin on airway neural responses in vitro. J. Appl. Physiol. 73:1537-1542.

43. Burgess, G. M., I. Mullaney, M. McNeill, P. M. Dunn, and H. P. Rang. 1989. Secondary messengers involved in the mechanism of action of bradykinin in sensory neurons in culture. J. Neurosci. 9:3314-3325.

44. Gounni, A. S., B. Lamkhioued, K. Ochial, Y. Tanaka, E. Delaporte, A. Capron, J.-P. Kinet, and M. Capron. 1994. High affinity IgE receptor on eosinophils is involved in defense against parasites. Nature (Lond.) 367:183-186. 